\title{
Supply chain management practices as a competitive tool for third party logistics providers performance
}

\author{
Conrad Ochego Mogaka *, Kellen Karimi Njiru *, Wycliffe Arani ** \\ * Department of Procurement and Logistics, School of Entrepreneurship, Procurement and Management, \\ Jomo Kenyatta University of Agriculture and Technology, Kenya \\ mogakaconrad@gmail.com; kellynguyo@gmail.com \\ ** Faculty of Business and Economics, Multimedia University of Kenya, Kenya \\ araninemuel@gmail.com
}

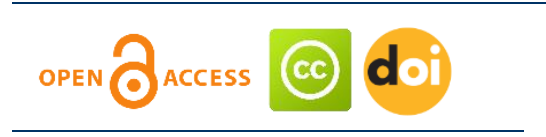

Article history:

Received: August 14, 2020

1st Revision: September 26,

2020

Accepted: November 07,

2020

DOI:

10.14254/jsdtl.2020.5-2.13

\begin{abstract}
The major purpose of this research paper is to examine supply chain management practices as a strategic tool for third-party logistics firms' performance: by presenting practical and theoretical advantages by reviewing the corresponding literature, and also by proposing more forwardlooking studies. A literature review was developed to help today's supply chain managers and analysts to thoroughly scrutinize what was already recognized as well as what requires further research. The research broadens, from a centered company perspective, the understanding of supply chain management practices as a tactical resource for success of third party logistics firms, as well as limitations for future studies. This research paper presents a comprehensive analysis of the literature to develop a proposed general framework for a strategic tool research initiative to perform TPLs' supply chain management practices. The research paper provides perspectives into deficiencies in current practices of supply chain management, along with the progress of third party logistics sector literature. The research paper proposes specific research into the logistics process, as it relates to planned and current performance. The research paper makes a series of important literary contributions. First, it provides the first comprehensive analysis of the fundamental concepts used throughout the current supply chain management activities research in relation to the performance of third party logistics companies. Indeed, when carrying out a similar exercise, the approach used to conduct the systematic literature review may be used as a guide for future investigators. Current research is aimed at providing a researcher who meets the needs of modern business leaders.
\end{abstract}

Keywords: competitive tool, supply chain management practices, performance, third party logistics firms. 


\section{Introduction}

Today international rivalry and competition is pushing manufacturers to collaborate with 3PLs as a strategic partners. 3PL may be well-defined as a contractual supplier of a single or multiple logistics service to a client enterprise's logistics undertakings (Abdur-Razzaque \& Sheng, 1998). Academics term logistics outsourcing 3PL, services of contract logistics and external logistics (Zailani et al., 2017). 3PL services include storage \& warehousing, inventory control, handling of goods, reverse logistics, crossdocking, transportation, freight forwarding, information services and customer support (Ellinger et al., 2008; Payaro \& Papa, 2017). Yet 3PL has not only done these, but also performed several value-added operations not limited to packaging, processing of orders, bar coding among others (Mothilal et al., 2012).

According to Kentchen and Hult (2007), SCM is a fundamental component of value chains in companies that is crucial to their (firms') performance. SCM includes a multifaceted set of systems and processes, including sourcing and procurement; designing products, developing products; planning collaboratively, forecasting, replenishment plus distribution (Chen \& Paulraj, 2004). Successful and effective implementation of these systems is important for productivity and performance, and sustainable competitive advantage. Companies are thus making significant investments (in millions of dollars) on the implementation of various SCMPs, information technology (ITs), the development and productivity of these systems (Rai, Patnayakuni \& Seth, 2006). Execution of these systems involves major modifications in SCM practices \& processes, plus preceding researchers and practitioners' literature reviews have recognized major setbacks faced by firms when incorporating and regularizing these changes (Oliva \& Watson, 2009).

The link between numerous measures of SCMP \& SC performance is a widely prominent investigation area that has led to a considerable body of academic work, for instance Gunasekaran \& Kobu (2007), Petrovic-Lazarevic, Sohal \& Baihaqi (2007), Van der Vaart \& van Donk (2008), Sundram, Ibrahim \& Govindaraju (2011), Sukati, Hamid, Baharun \& Yusoff (2012), Rexhausen et al. (2012), and Ibrahim \& Hamid (2014). A systematic analysis of the literature has developed two structures to help comprehend the antecedents and consequences of SCMP.

\section{Supply Chain Management Practices - SCMP}

SCMP is well-defined as a group or set of processes or activities undertaken in a firm to facilitate operational management of its SC (Ibrahim \& Hamid, 2014). Donlon (1996) and Birasnav (2013), discusses the emerging implementation of SCMP, which includes cooperation with the supplier, reduction of the cycle time, continuous process flow, outsourcing, as well as sharing of IT. Wisner (2003), noted that along with ultimate objectives of supply management comprising of greater satisfaction of the customer and a competitive advantage. The researcher also asserted that perhaps the incorporated SCMP of the organization, including the partnerships (strategic) or structured and organized strategies for supplier growth and development, information transfer and sharing, quality of data and information, could have a bearing on relativity of the firm's competitiveness.

Talluri and Narasimhan (2004), well-defined integrated SCM as a method for successful and productive supplier base optimization and management, that indeed has a valuable impact on the general firm performance and competitiveness (Chen \& Paulraj, 2004), raising the value of optimized supply strategies (Elmaghraby, 2000). Founded on the comprehensive review of literature, SCMP is approached from multiple viewpoints with a common aim to increase organizations efficiency which leads to performance and competitiveness.

\section{Methodology}

Defining clear boundaries for research delimitation for an organized literature review (Seuring \& Muller, 2008) is essential, and thus establishing a process for classifying, choosing, \& thoroughly reviewing scholarly literature more appropriate to the particular issue at hand. This type of analysis normally has the three distinct prepping steps are research needs and issues are recognized; conducting what involves the review and evaluation of relevant literature; and reporting where even the findings are formalized but also recommendations are provided (Tranfield, Denyer \& Smart, 2003). 
Comprehensive analysis of systematic relevant literature in the field of Operations Management (Seuring \& Muller, 2008) illustrate the analytical importance of this approach in the identification of main subjects or parameters, and the opportunities that may be offered to advancing imminent research (Squire, Burgess, Singh \& Koroglu, 2006). This methodology, as well as analyzing content as in a traditional procedure of analyzing literature, explores the essential structure of the particular articles in order to consider discrepancies and correspondences in the approaches utilized and possible matters that emerge from all. It tests analytical skills and identifies critical information gaps in knowledge.

Tranfield, Denyer and Smart (2003), poised that extensive literature reviews play a noteworthy part in the compilation and sharing of information throughout the management discipline as an instrument of academic and scientific study. The existing literature comprehensive review approach includes robust application of research methodology and thoroughness (Briner \& Denyer, 2012). The value of literature reviews in evaluating, disseminating, and mapping the intellectual domain of a research area is unmatched (Tranfield, Denyer \& Smart, 2003). Such evidence grounded approach of analysis follows a methodical and clear scheme which aims to exploit reliability whereas maintaining a high degree of transparency and the scientific prejudice in each phase of the study progression (Rousseau, Manning \& Denyer, 2008). Moreover, the meticulous planning of the study procedure guarantees that it is verifiable, plus the review can be repeated by more investigators (Seuring \& Gold, 2012).

Several scholars including (Seuring \& Gold, 2012) have recommended using content analysis (qualitative study) as an effective instrument for thorough, systematic and replicable study of SCM literature. Use of a simpler version of the analysis of content methodology proposed (Mayring, 2010), as cited by Seuring \& Gold (2012), to evaluate aspects of both formal qualitative and quantitative content in the literature examined. Analysis of content is an effective approach for conducting systematic evaluations of SCM literature. This four-step framework to content analysis focused, is used in this research paper to apply the methodology of reviewing literature systematically.

\section{Systematic Literature Review}

Interchangeably are used the words "third-party logistics," "logistics outsourcing," 3PL, or "TPL," "contract logistics," "logistics partnerships" (Lieb, Millen, and Van Wassenhove, 1993; Eidem \& Kristiansen, 2009; Abdur-Razzaque \& Sheng, 1998; Shah \& Chao, 2010; König \& Spinler, 2016). However, the definitions are often not well detailed in the existing literature and vary from simple transport or warehousing, procurement to outsourcing of entire highly sophisticated logistics operations (Van Laarhoven, Berglund \& Peters, 2000).

Traditionally, the shipping company and LSP have an "arms-length" relationship with a restricted information exchange and a concentration on reductions of cost. Nonetheless, competitive advantages of long-term supplier relationships and customer relationships can indeed be achieved by LSPs. Therefore more collaborative, long-term alliances or partnerships can be formed (Bowersox, 1990; Kremic et al., 2003), specifically as managers view satisfaction of customers and quality as being more sustainable than cost reductions presently. Although Solakivi et al. (2011), doesn't really find a direct relationship between the outsourcing of logistics and its cost or quality or performance and that costs and efficiency or performance can be optimized. In general, the results of their outsourcing operations often frustrate the executives (Lonsdale, 1999).

Li, Rao, Ragu-Nathan and Ragu-Nathan (2005), regarded SCM practices also as a collection of undertakings or activities conducted by an organization to enhance the integrated management of its supply chain. Researchers identified six dimensions of SCM comprehensive literature review and integration activities: strategic supplier partnerships, relationships with clienteles, sharing of quality information, operational lean practices but also postponement. In this, Cigolini, Cozzi and Perona (2004), describes the methods of SCM as approaches used by managers to evaluate how the chain operates.

The Lieb and Lieb study (2010) incorporates the studies which follow the second approach. The findings since the global recession show that several large 3PLs have actually augmented their level of commitment and dedication to establishing sustainability initiatives for the global changing environment. Pieters, Glockner, Omta and Weijers (2012) explored in what way the alterations in the 3PLs' sustainability plan affect the expansion of various types of physical distribution networks 
on the Dutch market. The investigators surveyed 145 businesses in the Dutch logistics industry. The investigation's findings suggest that many of the strategies implemented were in-house based.

\section{Findings}

Cigolini, Cozzi \& Perona (2004), and Li, Rao, Ragu-Nathan and Ragu-Nathan (2005), discovered the impact of scholarly research to SCM practice was minimal, given the large stream of studies in this thematic area. They attributed this not just to the multidisciplinary approach of SCM but also to its adaptive features, which they thought created a methodological uncertainty in their interpretation. As these conditions may have contributed to a difference comparing the theory of SCM and its applicability in practice. The systematic feature of the investigation conducted could also have greatly contributed towards this.

Scholarly work of the specific SCMPs embraced by particular regions, nations and industries therefore requires an understanding of their distinctive features within particular contexts. Thus this helps close the difference between the theory of SCM and its application. Various SCM investigations have been done in specific sectors, including the automotive industry (Blos, Quaddus, Wee \& Watanabe, 2009), pharmaceutical (Papalexi, Bamford \& Dehe, 2016), toy (Wong, Arlbjørn \& Johansen, 2005), apparel or textile (Abylaev, Pal \& Torstensson, 2014), chemical (Foerstl, Reuter, Hartmann \& Blome, 2010), telecommunications (Reyes, Raisinghani \& Singh, 2002), food \& beverages (Wambua, Mukulu \& Waiganjo, 2017), aerospace (Sinha et al., 2004), electronics (Foerstl, Reuter, Hartmann \& Blome, 2010).

Similarly, studies on different aspects of the SCM continues to concentrate on industrialized nations compared to their relations with emerging markets and economies as sources of supply, as well as on other emerging nations including Kyrgyz Republic (Abylaev, Pal \& Torstensson, 2014), Taiwan (Chow et al., 2008), Brazil (Diniz \& Fabbe-Costes, 2007), plus China (Zhu et al., 2007) among others. All together, these results reflect the efforts of the researchers to comprehend SCMPs across different contexts in industry and region.

Despite this, nevertheless, there is indeed a shortage of SCM researches regarding the practices which manufacturers need to implement in emerging nations to create existing supply chains a significantly competitive interface for growth. Jordan's political, economic, but also geographic attributes, including its present state of rapid growth in the manufacturing industry, and also its feasible entry to Northern Africa as well as the Middle East, end up making supply chains distinct from those previously studied in its manufacturing sector (Zhu, Zhang \& Tsung, 2007; Abylaev, Pal \& Torstensson, 2014).

\section{SCMP - Supply Chain Management Practices}

Grounded on a rapidly increasing volume of research effort on the association between performance of SCM, performance of logistics plus strategic management (Hult, Craighead \& Ketchen, 2010), it could be concluded that senior management is supposed to participate actively in understanding the strategic importance of practices in SCM. The correlation concerning practices in SCM and corporate strategy, as well as the means to enhance logistics processes and activities, is consequently becoming a senior management concern. The support of senior management to counter short-term thinking on Wall Street is analogous to that. Investment decisions in SCM operations, including alliances and Information Technology services, are characteristically long-term; hence senior executives must expect stability from stakeholders and shareholders and watch over periodic pressures (Slone, Upala, Gonce \& Tweney, 2007).

\section{Supply Chain Management Practices and Performance of Third Party Logistics Providers}

As retailers dramatically reduced supply but also lead times, unparalleled efficiency levels emerged (Fernie, Bird, Dawson \& Laguë, 2000). As noted by Smith and Sparks (2004), additional efficiencies as well as cost savings ensued when merchants used 3PL services. Similarly, the LSPs have advanced their competences in line with diverse product portfolio and service solutions targeted to 
different segments of the customer or business. As a result, large sections of supply chains are put (externally) outside their borders in an increasing number of businesses.

Firm performance is a compound term which shows the firm profitability. This relates in particular to how a certain firm is reaching its commercial, operational and marketplace goals (Li, RaguNathan, Ragu-Nathan \& Rao, 2006). The immediate SCM objectives are primarily to decrease inventory, maximize profitability plus decrease product, process and service cycle times. The long-standing SCM goals are to grow revenues, penetrate novel markets, quality improvement and proliferation of the marketplace share for SC systems (Tan, Handfield \& Krause, 1998). To attain optimal market efficiency, activities, such as those of SCs, need to be matched or linked with financial measures (Fraser, 2006).

In this context Fraser (2006) poises that the advanced the mechanism for measuring and tracking financial and operational performance of the organization, the higher the finances \& operations. Considering the impact SCMPs have on the financial performance of manufacturing companies is therefore of great importance. This is done in this study, via the MFP system. This domain is still used in indicators of performance, in line with previous studies that identify firms ' financial and market performance (Li, Ragu-Nathan, Ragu-Nathan \& Rao, 2006).

The SCM must be applied (Marien, 2000), and the dedication and appreciation of senior executives is consequently an important beginning point for SCM (Fawcett, Ogden, Magnan \& Cooper, 2006). SCMskilled CEOs should correspondingly have the ability to assess the efficiency of the supply chain accurately, revised as revealed by Slone et al. (2007). The logistics industry comprises railway companies, businesses in the road transport business, air freight firms, ports \& shipping firms, intermodal transport service providers, plus 3PL firms. Their performance, efficiency and competitiveness is analytically reliant on the state of the infrastructure and connectivity of railways, roads, airports and sea ports.

Conversely, additional changes in performance of the supply chain and efficiency will include speedy sharing of order information to SC partners in the upstream and speeding up logistics operations including storing besides delivering products or goods across the SC network (Bhatnagar, Khanna \& Gust, 1999). Contemporary studies on SCMP in India revealed that growing \& developing the Indian economy but also SC globalization has always been a critical aspect for the industry in India to integrate SC policy with corporate strategy, rationalize supply chain integration procedures \& practices but also form partnerships, collaborations or alliances to reduce inventory levels. Sahay and Mohan (2003), noted that Indian businesses are progressively implementing SC strategies to improve logistics operations to maximize sales revenues, raise returns and profits, minimize delivery lead-times plus reduce stocks or inventories.

Consequently, logistics operations will spring up in the future as a critical strategic frontier. Efficient logistics productivity entails a barter between the desire to decrease inventory plus lead-times throughout the entire supply chain whilst still achieving scale economies and improving customer service towards improved firm performance. Trunick (1989), established that adaptability of 3PL service providers helps them sustain this barter by spiraling fixed operating expenses into flexible expenses for firms utilizing their amenities. Utilizing 3PL firms has become much more common in this way.

Third party utilization of logistics services is a considered a tactical choice and the consequence it has on firm efficiency, competitiveness and performance requires to be measured. Skjott-Larsen (2000), noted that the goal of investing in relations (collaborative) with 3PLs is simply saving cost, nonetheless an amalgamation of enhanced value besides profitable operations. It is noteworthy that firms usually begin outsourcing some limited logistics services, move to operations which have the greatest influence on logistics productivity, then increase the scope of logistics services consumption together with anticipated and measureable effects on total firm performance and competitiveness.

\section{Suggested Research Agenda}

Although some current research has focused on 3PLs green sustainability in the Italian setting (Evangelista, Huge-Brodin, Isaksson \& Sweeney, 2011). Colicchia, Dallari and Melacini (2010) recommended advanced research in this thematic area. Zhu and Sarkis, (2004) also recommended research to be done mainly about the correlation between SCMP application and firm performance will require more attention. Throughout contemporary ever-changing competitive landscape the logistics 
operations are becoming highly multifaceted plus knowledge intensive. Understanding and information have turned out to be predominantly important for 3PLs to attain performance objectives.

\section{Limitations and conclusion}

Existing research has limitations such as; one of the recent research objectives was to provide an unbiased analysis of the essence of SCM as a competitive tool for third party logistics companies' competitiveness and performance. Current literature reviews are usually undertaken to promote the timely implementation of studies, not so much because the writers are thorough in-depth study. Nonetheless, a comprehensive literature review on the management of supply chain activities or practices besides reliability of specifications of 3PLs need to be established using a literature review's impartial approach to an emerging trend to keep the work progressing forward. This could have properly delineated the SCMP of the researchers besides technical effectiveness strategy of 3PL provider which deterred a narrow study of other existing areas of interest.

\section{Citation information}

Mogaka, C. O., Njiru, K. K., \& Arani, W. (2020). Supply chain management practices as a competitive tool for third party logistics providers performance. Journal of Sustainable Development of Transport and Logistics, 5(2), 143-152. doi:10.14254/jsdtl.2020.5-2.13.

\section{References}

Abdur Razzaque, M., \& Chen Sheng, C. (1998). Outsourcing of logistics functions: a literature survey. International Journal of Physical Distribution \& Logistics Management, 28(2), 89-107.

Abylaev, M., Pal, R., \& Torstensson, H. (2014). Resilience challenges for textile enterprises in a transitional economy and regional trade perspective: a study of Kyrgyz conditions. International Journal of Supply Chain and Operations Resilience, 1(1), 54-75.

Bhatnagar, S. K., Khanna, P. K., \& Gust, W. (1999). Analysis of packaging and sealing techniques for microelectronic modules and recent advances. Microelectronics international, 16(2), 8-12.

Birasnav, M. (2013). Implementation of supply chain management practices: The role of transformational leadership. Global Business Review, 14(2), 329-342.

Blos, M. F., Quaddus, M., Wee, H. M., \& Watanabe, K. (2009). Supply chain risk management (SCRM): a case study on the automotive and electronic industries in Brazil. Supply Chain Management: An International Journal, 14(4), 247-252.

Briner, R. B., \& Denyer, D. (2012). Systematic review and evidence synthesis as a practice and scholarship tool. Handbook of evidence-based management: Companies, classrooms and research, 112-129.

Chen, I. J., \& Paulraj, A. (2004). Towards a theory of supply chain management: the constructs and measurements. Journal of operations management, 22(2), 119-150.

Cigolini, R., Cozzi, M., \& Perona, M. (2004). A new framework for supply chain management: conceptual model and empirical test. International Journal of Operations \& Production Management, 24(1), 741.

Colicchia, C., Dallari, F., \& Melacini, M. (2010). Increasing supply chain resilience in a global sourcing context. Production planning \& control, 21(7), 680-694. 
Diniz, J. D., \& Fabbe-Costes, N. (2007). Supply chain management and supply chain orientation: key factors for sustainable development projects in developing countries?. International Journal of Logistics Research and Applications, 10(3), 235-250.

Eidem, L. L., \& Kristiansen, I. (2009). Vertical electronic coordination versus vertical electronic integration: a 3PL client perspective (Master's thesis, Høgskolen i Molde).

El Baz, J., \& Laguir, I. (2017). Third-party logistics providers (TPLs) and environmental sustainability practices in developing countries. International Journal of Operations \& Production Management.

Ellinger, C., Stierle, A., Robinson, I. K., Nefedov, A., \& Dosch, H. (2008). Atmospheric pressure oxidation of Pt (111). Journal of Physics: Condensed Matter, 20(18), 184013.

Elmaghraby, W. J. (2000). Supply contract competition and sourcing policies. Manufacturing \& Service Operations Management, 2(4), 350-371.

Evangelista, P., Huge-Brodin, M., Isaksson, K., \& Sweeney, E. (2011, January). The impact of 3PL's green initiatives on the purchasing of transport and logistics services: an exploratory study. In Proceedings of the 20th Annual IPSERA Conference Vision (Vol. 20).

Fawcett, S. E., Ogden, J. A., Magnan, G. M., \& Cooper, M. B. (2006). Organizational commitment and governance for supply chain success. International Journal of Physical Distribution \& Logistics Management.

Fernie, K. J., Bird, D. M., Dawson, R. D., \& Laguë, P. C. (2000). Effects of electromagnetic fields on the reproductive success of American kestrels. Physiological and Biochemical Zoology, 73(1), 60-65.

Foerstl, K., Reuter, C., Hartmann, E., \& Blome, C. (2010). Managing supplier sustainability risks in a dynamically changing environment-Sustainable supplier management in the chemical industry. Journal of Purchasing and Supply Management, 16(2), 118-130.

Gawankar, S. A., Kamble, S., \& Raut, R. (2017). An investigation of the relationship between supply chain management practices (SCMP) on supply chain performance measurement (SCPM) of Indian retail chain using SEM. Benchmarking: An International Journal, 24(1), 257-295.

Gawankar, S., Kamble, S. S., \& Verma, R. (2013). Development, measurement and validation of supply chain management practices scale in Indian retail sector. International Journal of Procurement Management, 6(5), 495-522.

Gunasekaran, A., \& Kobu, B. (2007). Performance measures and metrics in logistics and supply chain management: a review of recent literature (1995-2004) for research and applications. International journal of production research, 45(12), 2819-2840.

Hult, G. T. M., Craighead, C. W., \& Ketchen, Jr, D. J. (2010). Risk uncertainty and supply chain decisions: a real options perspective. Decision Sciences, 41(3), 435-458.

Hult, G. T. M., Ketchen, D. J., \& Arrfelt, M. (2007). Strategic supply chain management: Improving performance through a culture of competitiveness and knowledge development. Strategic management journal, 28(10), 1035-1052.

Ibrahim, S. B., \& Hamid, A. A. (2014). Supply chain management practices and supply chain performance effectiveness. International Journal of Science and Research, 3(8), 187-195.

König, A., \& Spinler, S. (2016). The effect of logistics outsourcing on the supply chain vulnerability of shippers. The International Journal of Logistics Management. 
Kremic, T. (2003). Technology transfer: a contextual approach. The Journal of Technology Transfer, 28(2), 149-158.

Li, S., Ragu-Nathan, B., Ragu-Nathan, T. S., \& Rao, S. S. (2006). The impact of supply chain management practices on competitive advantage and organizational performance. Omega, 34(2), 107-124.

Li, S., Rao, S. S., Ragu-Nathan, T. S., \& Ragu-Nathan, B. (2005). Development and validation of a measurement instrument for studying supply chain management practices. Journal of operations management, 23(6), 618-641.

Lieb, K. J., \& Lieb, R. C. (2010). Environmental sustainability in the third-party logistics (3PL) industry. International Journal of Physical Distribution \& Logistics Management, 40(7), 524-533.

Lieb, R. C., Millen, R. A., \& Van Wassenhove, L. N. (1993). Third party logistics services: a comparison of experienced American and European manufacturers. International Journal of Physical Distribution \& Logistics Management, 23(6), 35-44.

Lonsdale, W. M. (1999). Global patterns of plant invasions and the concept of invasibility. Ecology, 80(5), 1522-1536.

Mayring, P. (2010). Qualitative inhaltsanalyse. In Handbuch qualitative Forschung in der Psychologie (pp. 601-613). VS Verlag für Sozialwissenschaften.

Mothilal, S., Gunasekaran, A., Nachiappan, S. P., \& Jayaram, J. (2012). Key success factors and their performance implications in the Indian third-party logistics (3PL) industry. International Journal of Production Research, 50(9), 2407-2422.

Oliva, R., \& Watson, N. (2009). Managing functional biases in organizational forecasts: A case study of consensus forecasting in supply chain planning. Production and Operations Management, 18(2), 138-151.

Papalexi, M., Bamford, D., \& Dehe, B. (2016). A case study of kanban implementation within the pharmaceutical supply chain. International Journal of Logistics Research and Applications, 19(4), 239-255.

Payaro, A., \& Papa, A. R. (2017). Logistics Outsourcing: Why Do Not Some Italian SMEs Adopt the Externalization?. Asian Business Research, 2(2), 46.

Petrovic-Lazarevic, S., Sohal, A., \& Baihaqi, I. (2007). Supply chain management practices and supply chain performance in the Australian manufacturing industry. Monash University Faculty of Business and Economics.

Pieters, R., Glockner, H.H., Omta, O. and Weijers, S. (2012), "Dutch logistics service providers and sustainable physical distribution: searching for focus", International Food and Agribusiness Management Review, 15, Special issue B, 107-126

Rai, A., Patnayakuni, R., \& Seth, N. (2006). Firm performance impacts of digitally enabled supply chain integration capabilities. MIS quarterly, 225-246.

Rexhausen, D., Pibernik, R., \& Kaiser, G. (2012). Customer-facing supply chain practices-The impact of demand and distribution management on supply chain success. Journal of Operations Management, 30(4), 269-281.

Reyes, P., Raisinghani, M. S., \& Singh, M. (2002). Global supply chain management in the telecommunications industry: the role of information technology in integration of supply chain entities. Journal of Global Information Technology Management, 5(2), 48-67. 
Rousseau, D. M., Manning, J., \& Denyer, D. (2008). 11 Evidence in management and organizational science: assembling the field's full weight of scientific knowledge through syntheses. Academy of Management Annals, 2(1), 475-515.

Rousseau, R., \& Jin, B. (2008). The age-dependent h-type AR2-index: Basic properties and a case study. Journal of the American Society for Information Science and Technology, 59(14), 2305-2311.

Saad, S. M., Baykasoglu, A., \& Gindy, N. N. Z. (2002). An integrated framework for reconfiguration of cellular manufacturing systems using virtual cells. Production Planning \& Control, 13(4), 381-393.

Sahay, B. S., \& Mohan, R. (2003). Supply chain management practices in Indian industry. International Journal of Physical Distribution \& Logistics Management, 33(7), 582-606.

Seuring, S., \& Gold, S. (2012). Conducting content-analysis based literature reviews in supply chain management. Supply Chain Management: An International Journal, 17(5), 544-555.

Seuring, S., \& Müller, M. (2008). From a literature review to a conceptual framework for sustainable supply chain management. Journal of cleaner production, 16(15), 1699-1710.

Shah, M. A., \& Chao, H. (2010). "Logistic Outsourcing Process in SMEs"-Case Studies of Four Taiwanese SMEs.

Sinha, P. M., Valco, G., Sharma, S., Liu, X., \& Ferrari, M. (2004). Nanoengineered device for drug delivery application. Nanotechnology, 15(10), S585.

Slone, D. J., Upala, M. A., Gonce, L. O., \& Tweney, R. D. (2007). Contextualizing counterintuitiveness: How context affects comprehension and memorability of counterintuitive concepts. Cognitive Science, 31(3), 415-439.

Squire, B., Burgess, K., Singh, P. J., \& Koroglu, R. (2006). Supply chain management: a structured literature review and implications for future research. International journal of operations \& production Management.

Sukati, I., Hamid, A. B., Baharun, R., \& Yusoff, R. M. (2012). The study of supply chain management strategy and practices on supply chain performance. Procedia-Social and Behavioral Sciences, 40, 225-233.

Sundram, V. P. K., Ibrahim, A. R., \& Govindaraju, V. G. R. (2011). Supply chain management practices in the electronics industry in Malaysia: Consequences for supply chain performance. Benchmarking: An International Journal, 18(6), 834-855.

Talluri, S., \& Narasimhan, R. (2004). A methodology for strategic sourcing. European journal of operational research, 154(1), 236-250.

Tan, K., Handfield, R. B., \& Krause, D. R. (1998). Enhancing the firm's performance through quality and supply base management: an empirical study. International Journal of production research, 36(10), 2813-2837.

Tranfield, D., Denyer, D., \& Smart, P. (2003). Towards a methodology for developing evidence-informed management knowledge by means of systematic review. British journal of management, 14(3), 207222.

Van der Vaart, T., \& van Donk, D. P. (2008). A critical review of survey-based research in supply chain integration. International journal of production economics, 111(1), 42-55. 
Van Laarhoven, P., Berglund, M., \& Peters, M. (2000). Third-party logistics in Europe-five years later. International Journal of Physical Distribution \& Logistics Management, 30(5), 425-442.

Wambua, J., Mukulu, E., \& Waiganjo, E. (2017). Cost as a Factor of Outsourcing Third-Party Logistics Providers and the Performance of Food and Beverages Manufacturing Companies in Kenya. International Journal of Academic Research in Business and Social Sciences, 7(2), 343-356.

Wisner, J. D. (2003). A structural equation model of supply chain management strategies and firm performance. Journal of Business logistics, 24(1), 1-26.

Wong, C. Y., Arlbjørn, J. S., \& Johansen, J. (2005). Supply chain management practices in toy supply chains. Supply Chain Management: An International Journal, 10(5), 367-378.

Zailani, S., Iranmanesh, M., Aziz, A. A., \& Kanapathy, K. (2017). Halal logistics opportunities and challenges. Journal of Islamic Marketing, 8(1), 127-139.

Zhu, K., Zhang, R. Q., \& Tsung, F. (2007). Pushing quality improvement along supply chains. Management science, 53(3), 421-436.

Zhu, Q., \& Sarkis, J. (2004). Relationships between operational practices and performance among early adopters of green supply chain management practices in Chinese manufacturing enterprises. Journal of operations management, 22(3), 265-289.

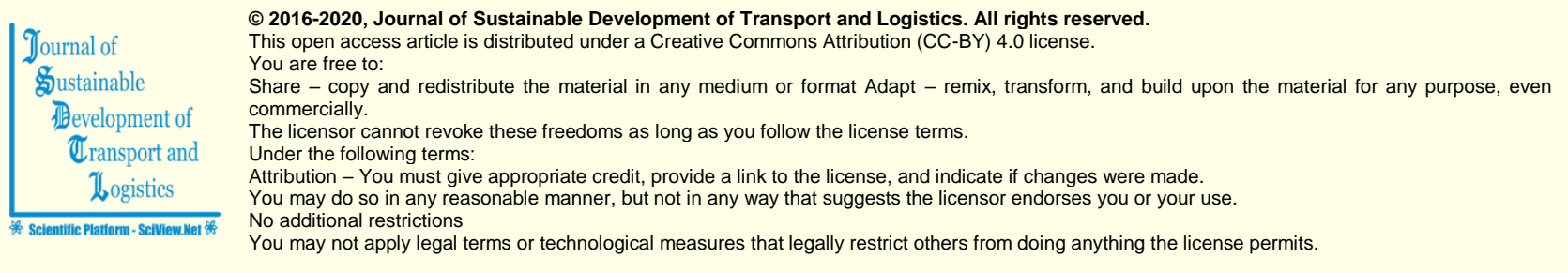

Journal of Sustainable Development of Transport and Logistics (ISSN: 2520-2979) is published by Scientific Publishing House "CSR", Poland, EU and Scientific Publishing House "SciView", Poland, EU

Publishing with JSDTL ensures:

- Immediate, universal access to your article on publication

- High visibility and discoverability via the JSDTL website

- Rapid publication

- Guaranteed legacy preservation of your article

- Discounts and waivers for authors in developing regions

Submit your manuscript to a JSDTL at https://jsdtl.sciview.net/ or submit.jsdt|@sciview.net 